\title{
CUTTING THE GORDIAN KNOT OF WORLD HISTORY: GIOVANNI ARRIGHI'S MODEL OF THE GREAT DIVERGENCE AND CONVERGENCE
}

\author{
Jan-Frederik Abbeloos \\ History Department (Research Group Communities Comparisons Connections) \\ Ghent University \\ janfrederik.abbeloos@ugent.be \\ Eric Vanhaute \\ History Department (Research Group Communities Comparisons Connections) \\ Ghent University \\ eric.vanhaute@ugent.be
}

\begin{abstract}
This essay evaluates the new road Giovanni Arrighi paves in Adam Smith in Beijing (2007) in relation to the scholarly debate on Europe's Great Divergence and the remarkable resurgence of East Asia in the global economy at the end of the twentieth century. At the center of Adam Smith in Beijing is the argument that the probability has increased that we are witnessing the formation of an "East Asian-centered world-market society," rivaling the historical "capitalist worldeconomy". We show how Arrighi's discovery of East Asia has led him to supplement the analysis of historical capitalism he presented in The Long Twentieth Century (1994). This brings about uncertainties and problems. On the one hand, Arrighi is clear in his view on the different paths of economic development followed by the Europe-centered capitalist world-system, and the Chinese-centered market-oriented world-system. These paths remained largely separate until deep into the nineteenth century. On the other hand, Arrighi is less clear on how the Asian market-oriented legacy survived its incorporation into a globalizing capitalist world-economy, a crucial precondition for Arrighi's political message. Characterized as a process of subordination, hybridization, or fusion, it remains difficult to extract from Arrighi an unambiguous understanding of the place of China and East Asia within the capitalist worldsystem. It is just as hard to understand the nature of that "interstitial" system itself. These conceptual and theoretical uncertainties suggest a central question and problem that hangs over Adam Smith in Beijing: What remains of the capitalist world-system as an analytical category that allows us to understand economic history and our possible futures?
\end{abstract}

\section{INTRODUCTION}

In this paper we focus on the "Asian turn" that Arrighi has taken on his long march to historical sociology, a turn that became visible with The Long Twentieth Century (1994) and which came full circle in Adam Smith in Beijing. ${ }^{1}$ At the center of Arrighi's Asian turn is the debate over what

\footnotetext{
${ }^{1}$ For an evaluation of the long march to historical sociology see Arrighi 2009.
} 
Pomeranz (2000) calls the "Great Divergence" between the economic growth trajectory of the industrializing economies (often labeled as the West) and The Rest since 1800, a divergence that started "big time" after 1870 (Pritchett 1997). This divergence broke through after England and other national economies made the transition from an organic to a mineral-based fossil-fuel economy and unbounded the Prometheus of technology-based and capital-intensive persistent economic growth (Landes 1969; Wrigley 1988). The mechanization of production not only loosened the Malthusian constraints that typified pre-industrial societies, it also pushed the productive and military strength of the early European industrializers to unprecedented heights, resulting in their worldwide economic and geopolitical dominance by 1900 . Around that time, Max Weber wondered "to what combination of circumstances the fact should be attributed that in Western civilization, and in Western civilization only, cultural phenomena have appeared which (as we like to think) lie in a line of development having universal significance and value." (Weber 2003:13). Since Weber, a lot has been written on the combination of circumstances that lay behind "The Rise of the West" (McNeill 1992) or the "European Miracle" (Jones 1981; also see Van Zanden 2008). Nevertheless, opinions differ greatly on whether Europe's development of large-scale mechanized industry was primarily a homegrown achievement or the result of its position within the networks of commerce and empire that have gradually circumscribed the world (for a review see Vries 2009).

For a long time this historical problem suffered from a classic case of Eurocentrism. Whether one searched the origins to the industrial take-off primarily internal to WesternEuropean societies, as did Weber or Marx, or found them in the imperial space that Great Britain commanded, as did Eric Williams (1944), it is clear that lot of studies hardly went beyond the European experience. The problem with this approach is that it left many hypotheses regarding the technological, institutional, social, political or geographical conditions within Great-Britain, Europe or the West unchecked, lacking a comparative framework that could help to identify which conditions were in retrospect necessary or sufficient to set a handful of European economies on the road to industrialization and global domination. Fernand Braudel admitted to this blind spot in his magnum opus Civilization and Capitalism (1981, 1982, 1984). Braudel lamented the "historiographical inequality" between Europe and the rest of the world, with a European history that was well-lit versus the history of "non-Europe" that was still to be written:

And until the balance of knowledge and interpretation has been restored, the historian will be reluctant to cut the Gordian knot of world-history - that is the origin of the superiority of Europe. [...] One thing seems clear to me: the gap between the West and the other continents appeared late in time [...]. By mechanizing, European industry became capable of out-competing the traditional industry of other nations. The gap which then opened up could only grow wider as time went on. The history of the world between about 1400 and $1850-1950$ is one of an ancient parity collapsing [...]. Compared with this predominant trend, everything else is secondary (Braudel 1982:134; 1984:535).

For many world-systems analysts, the question of industrialization and the subsequent, yet relatively late, "collapsing of an ancient parity" is - almost by definition - endogenous to the long-term operations of an expanding capitalist world-system. As a consequence, industrialization tends to receive short shrift when explaining the major transformations in global economic 


\section{JOURNAL OF WORLD-SYSTEMS RESEARCH}

history. In the third volume of The Modern World-System, Wallerstein reduces eighteenth century British industrialization from one of those "traditional lodestars by which to navigate the misty and turbulent waters of modern historical reality" to a mere footnote in the consolidation and entrenchment of the capitalist world-system (Wallerstein 1989:256). Much like Wallerstein, Arrighi is influenced by John Nef (1934) and claims that there have been different moments of industrial expansion in England (in the fourteenth, sixteenth/early seventeenth, and late eighteenth centuries), all integral to an ongoing expansion, restructuring, and reorganization, of a European capitalist world-economy, in which England was incorporated from the very start (Arrighi 1994:209; Wallerstein 1984:33). Andre Gunder Frank adds to this scheme that the first industrial expansion "improved England's competitive position only relative to Flanders, and the second only relative to northern and southern Europe. The third adjustment finally managed significantly to alter Britain's competitive position worldwide." (Frank 1998:290)

Recent research adds new support to the thesis that the emergence of industrialization in Britain should indeed be understood in the context of Britain's accumulated advantages in an expanding commercial and imperial system, creating a high wage economy in which there was systematic incentive to invent and implement technologies that substituted capital and coal for labor (see Allen 2009; Findlay and O'Rourke 2007; Flynn \& Giráldez 2004, 2008; Pomeranz 2000; Sugihara 2003; but compare to Goldstone 2009; Vries 2005, 2008). In doing so, many scholars have looked across Eurasia in order to compare the European developmental trajectory with East Asia's (see Little 2008). Two explanations account for the popularity of these comparisons. First, regarding the historical debate on the Great Divergence, the scientific and economic development of China in the centuries prior to the divergence makes it all the more puzzling why industrialization and the subsequent rise to global power did not happen East but West. Second, the vitality of Euro-American/Western hegemony today seems less secure than ever before. The economic "miracles" of Japan, the Asian tigers, and most recently China, beg the question if we are witnessing "The Rise of East Asia" and to what extent this "Rise" also implies the "Descent of the West" (Ferguson 2006:596-646)? Or does it point to a "Great Convergence", a catch-up process in economic and political development between the two sides of the Eurasian landmass, and perhaps between The West and The Rest (Sachs 2008:24)? ${ }^{2}$

In Adam Smith in Beijing, Arrighi takes this scholarship on board to analyze the global origins and consequences of the Great Divergence from the theory of historical capitalism

\footnotetext{
${ }^{2}$ The idea of an economic "Rise of The East" or a "Great Convergence" can be evaluated in different ways. Andrew Glyn (2005) notes that China doubled its ratio of per capita GDP compared to the USA over the past 20 years. This accounts for all the reduction in the inequality of the distribution of income on a world scale, and makes up for all the collapsed output share of the ex-Soviet Union and Eastern Europe and much of the downward drift in the share of Europe and Japan. Meanwhile, Glyn finds that China's per capita GDP is still as far behind the USA as Korea and Taiwan were before their three decades of rapid catch-up beginning in the late 1960s. The fundamental point to Glyn therefore is the surge in the combined growth of China, India and other developing countries and the fact that since the mid 1990s the majority of world GDP growth has been produced outside the founding OECD countries. The fundamental point for Arrighi could be said to be the key role that China fulfils in this combined surge as an increasingly significant importer of commodities and resources from developing countries, creating thus an alternative market for their products outside the OECD. In both cases, the central point of debate is of course if this relative rise in productivity and market should be interpreted as the first signs of an emerging, Asian or Sino-centered, global economy.
} 
presented in The Long Twentieth Century. Arrighi wants to construct a model of the Great Divergence that tells us something, not just about its origins, but also about its development over time, its limits, and its prospects. He goes beyond the history of the widening gap between the European industrializers and The Rest. For Arrighi "the really interesting question is [...] how and why China has managed to regain so much ground, so quickly after more than a century of political-economic eclipse" (Arrighi 2007a:32). Arrighi sees an increasingly likelihood that because of the Chinese resurgence we are witnessing the formation of an "East Asian-centered world-market society," rivaling the historical "capitalist world-economy." The central political message is that this change in the nature of the now-global world-economy might bring about a Great Convergence, bringing the different regions of the world closer together into the sort of Commonwealth of Civilizations that Adam Smith dreamt of.

Both propositions are far from self-evident and Adam Smith is a sophisticated attempt to substantiate both claims. With good reason, many reviewers have questioned Arrighi's characterization of present-day China as a non-capitalist society that can help to bring about this Commonwealth of Civilizations (Abbeloos 2008; Clark 2008; Coyne 2009; Dyer 2007; Gulick 2009; Trichur and Sherman 2009; Walden 2007). This essay primarily focuses on the analytical side of the story, on Arrighi's model for the Great Divergence and Convergence. What we want to underline is how much Arrighi has modified the original idea of China's "subordination to the Western commands" that was presented in The Long Twentieth Century. Instead, he has come to favor "hybridization" between two distinct paths of developments, one capitalist and one not. And within this hybrid construct he stresses the resilience of the market-logic that prevailed in China in particular (despite the active distortion of market forces up until 1979 and the active promotion of profit-seeking after 1979). In other words, Arrighi's hope for an East Asiancentered world-market society motivates a renewed understanding of The Long Twentieth Century. His additions and revisions nevertheless can be questioned, and bring new uncertainties and problems with regards to the scale and scope of world-systems research and its analytical concepts. On the one hand, Arrighi is clear that two distinct world-economies, one capitalist and one not, evolved on the East and West of the Eurasian landmass deep into the nineteenth century. On the other hand, he is less clear on what happened afterwards, once the two world-economies came into contact and The Great Divergence ran its course. Characterized as a process of subordination, hybridization, or formal dissolution, it remains hard to get an unambiguous understanding of the place of China and East Asia vis-à-vis the Euro-American networks of power and the expanding markets for capital, goods and services. Equally, it is unclear how Arrighi understands the functioning of these networks of power and markets, of this "interstitial" capitalist system. He sees a world in singular, denoted as "world capitalism", "world market" or "world-trading system" and there are worlds in plural that bear their own dynamic, such as the Global North and Global South. These conceptual uncertainties concerning the juxtaposition and permutation of two world-economies, one capitalist and one not, hinder Arrighi's attempts to cut the Gordian knot of the Great Divergence and Convergence.

\section{FROM THE LONG TWENTIETH CENTURY TO ADAM SMITH IN BEIJING}

As Thomas Reifer notes (2009:250), Adam Smith can be read as the third instalment of Arrighi's "unplanned trilogy", along with Chaos \& Governance in the Modern World System (1999) and 


\section{JOURNAL OF WORLD-SYSTEMS RESEARCH}

The Long Twentieth Century (1994). In The Long Twentieth Century Arrighi analyzes the changing relationships between the controllers of mobile capital and state power through the evolution of a capitalist world-economy that emerged some 700 years ago in Europe. According to Arrighi, this world-economy developed through successive systemic cycles of accumulation. Arrighi reconstructs the Genoese, Dutch, British, and American cycles of accumulation and discusses the successive forms of political exchange and the geographies they implied. Each cycle consists of a phase of material expansion, followed by one of financial expansion. During the first phase, the alliance between the governmental and capitalist agencies is based on the superior ability of the leading governmental agency to create a profitable investment regime which attracts capital from across its borders. During the phase of financial expansion, the hegemon looses this ability and gets overtaken by another organizational revolution, sustained by yet another governmental agency. However, before a new round of creative destruction takes place, the "old" capitalists still enjoy their phase of financial expansion. Capital pulls out of the productive, real sphere of the economy, and starts a temporary profitable retreat in the financial sphere, as has been visible during the Florentine Renaissance, the Dutch periwig period of the eighteenth century, the Edwardian Belle Epoque at the end of the nineteenth century and the globalizing nineties. All these episodes proved to be brief, only temporarily masking the underlying crisis in the spheres of production and trade which had in fact motivated the financialization of the economy. Out of such a period of systemic chaos a new regime of accumulation finally emerges and establishes the conditions for another cycle of accumulation (also see Arrighi 1999a). Important to note is that these cycles are cut through by a very important structural transformation of the capitalist world economy. From the United Provinces to the United States, from the merchant communities to the multinational corporations, Arrighi sees the recurrent emergence of new leading complexes of governmental and business agencies, more powerful, both militarily and financially, than the complexes they replace (1994:58,217). This evolution is accompanied by a greater specialization in the functions of state and business organizations. Arrighi in casu notices a transformation from a system in which networks of accumulation were embedded in and subordinate to networks of power into a system in which networks of power are embedded in and subordinate to networks of accumulation (1994:86).

Arrighi underlines that The Long Twentieth Century "lumps" together the insights of many intellectuals, amongst others Adam Smith, Karl Marx, Henri Pirenne, Max Weber, Joseph Schumpeter and Charles Tilly. But the book is especially indebeted to Braudel's account of early modern European history in Capitalism and Civilization (1981, 1982, 1984). Arrighi builds his analysis on three Braudelian principles that have shaped much of the world-systems paradigm. First is Braudel's idea of a world-economy (économie-monde, Weltwirschaft), which "concerns a fragment of the world, an economically autonomous section of the planet able to provide for most of its own needs, a section to which its internal links and exchanges give a certain organic unity" (Braudel 1984:22). Second is Braudel's insistence on the longue durée as the best temporal framework to analyze structural changes (1958). Third, and most important, is Braudel's understanding of capitalism. Braudel agreed "with the Marx who wrote [...] that European capitalism [...] began in thirteenth-century Italy" (Braudel 1984:57). By this, Braudel means that the Industrial Revolution might have changed the face of the earth, but it did not introduce the world to capitalism. As a consequence, Braudel renounces the reification of capitalism as a certain phase in economic history, triggered by the advent of industrialization. Instead, he regards capitalism to be the antonym of market competition. It is the wielding of monopoly power, the 
blocking out of market forces in favor of power relations, the establishment of non-markets or better, anti-markets. In that sense, economic activities that are multinational and highly skillful such as long distance trade, foreign exchange and credit arrangements for a long time in world history created much better opportunities vis-à-vis the sphere of production to achieve some sort of monopoly power. Braudel thus offers a critique, or assault as Wallerstein calls it, against the conflation by classical economists of the market and capitalism (Wallerstein 1991, 2004:18; also see Arrighi 2007b:266-267). But his understanding of capitalism also diverts from the Marxist necessity to reduce the concept of capitalism to a defined mode of production, next to other modes such as slavery or feudalism (Brenner 1977; Laclau 1971). What Braudel highlighted, and much of world-systems analysis builds upon, is that capitalism should not be seen as a certain mode of production but as certain mode of rule and accumulation that can, but needs not to, be based on wage labor.

Combining these three guiding principles, Arrighi restructured Braudel's panoramic view of European history into a series of systemic cycles of accumulation. ${ }^{3}$ In this recasting of Braudel's perspective, Arrighi however elides one of Braudel's most important contributions. For Braudel, capitalism, since it is little more than the manipulation of market forces towards monopoly power, was never a unique European phenomenon. Long distance trade for Braudel "lay at the heart of the most advanced capitalism in the Far East", although he admits that outside of Europe, "the merchants and bankers never had the stage to themselves", especially in "the aberrant case of China" where the imperial administration blocked any attempts at sustained capital accumulation (Braudel 1982:125, 136-137; 1984:520). In The Long Twentieth Century Arrighi, much more than Braudel, shows how in Europe the merchants and bankers also shared the stage of capital accumulation with the territorial and political aspirations of city-states and an emerging inter-state system. But in the end, this relationship between capital and power did create a European capitalist world-economy in Arrighi's view. Only through the consolidation and globalization of this European capitalist world-economy regions outside of Europe come into the picture, discussing their integration and subordination to a "capitalist" system". In this respect, Arrighi's discussion of historical capitalism mirrors Wallerstein's reconstruction of a modern capitalist world-system that globalized out of Europe since the sixteenth century (recapitulated by Wallerstein 1993). In both cases capitalism as a rule of accumulation is a priori considered to be a European characteristic. Furthermore, this quality is seen as the cornerstone of a social system. Both propositions radicalize Braudel's understanding of a European capitalist world-economy that is dependent on the economic spheres of market society and material life but does not dictate them. In the words of Braudel, we need to "think again before assuming that our societies are organized from top to bottom in a "capitalist system"" (Braudel 1984:630; also see Braudel 1982:239). As we will see now, this a priori equation between capitalism and a European, globalizing, system in The Long Twentieth Century creates the problems Adam Smith needs to resolve.

\footnotetext{
${ }^{3}$ Or as he said to Harvey: "Braudel is an incredibly rich source of information about markets and capitalism, but he has no theoretical framework. [...] You can't simply rely on Braudel; you have to approach him with a clear idea of what you are looking for, and what you are extracting from him" (Arrighi 2009: 71).
} 


\section{JOURNAL OF WORLD-SYSTEMS RESEARCH}

\section{Can Capitalism Survive Success?}

In the epilogue of The Long Twentieth Century, Arrighi poses the same question that Braudel and Schumpeter (1976) have asked before him: "Can capitalism survive success?" To Braudel this was a rhetorical question since he did "not have the impression that capitalism is likely to collapse of its own accord, in some form of 'endogenous' deterioration; for any collapse to take place, there would have to be some external impact of great violence; and a credible alternative would have to be available." (Braudel 1984:626) Both Wallerstein and Arrighi diverge from Braudel on this point. Wallerstein emphasizes how a set of secular trends gradually contradicts the possibilities for accumulation within the capitalist system: on the one hand rising costs of production and on the other hand sales prices that do not keep pace due to increased competition no matter how successful the constant attempts to keep competition at bay (Wallerstein 2004:83). He believes these secular trends already began to reach their limit some forty years ago and that the capitalist world-system has entered an "age of transition". For Wallerstein, the outcome of this crisis is uncertain, stressing the ability and necessity of social forces to stimulate the creation of a more egalitarian system of political economy for the future (Wallerstein 2005:1272-1277).

Arrighi focuses on the systemic expansion of the networks of power and accumulation during the cycles of accumulation we discussed above. Extrapolating this secular trend, Arrighi constructs three scenarios that all mark "the end of capitalism as we have known it." In the first scenario, the extent of the state- and war-making capabilities of the United States and its European allies creates the first true global empire, pacifying interstate relations by appropriating the surplus accumulation worldwide through force, cunning or persuasion. This would terminate capitalist history by terminating inter-state competition, a central drive behind the capitalist world-system. The second option sees the world slipping into a sort of systemic chaos out of which capitalism had emerged some seven centuries ago, again signaling the end of capitalism as a system. In the third scenario capitalist history would come to an end through the re-centering of the world-economy in East-Asia:

East Asian capital may come to occupy a commanding position in systemic processes of capital accumulation. [...] capitalist history $[\ldots]$ would come to an end as a result of the unintended consequences of processes of world market formation. Capitalism (the "anti-market") would wither away with the state power that has made its fortunes in the modern era, and the underlying layer of the market economy would revert to some kind of anarchic order (Arrighi 1994:355-356).

The main argument of Adam Smith in Beijing is that the third scenario has become increasingly likely: an "East Asian-centered world-market society" is going to replace the present day "capitalist world-economy" (Arrighi 2007a:7). This change in the nature of the world-economy according to Arrighi is triggered by the United States' failed Project for a New American Century (undermining its hegemonic status), and the continuing shift in the epicenter of the global political economy to East Asia. Contrary to The Long Twentieth Century, however, East Asia no longer points to the capitalist archipelago of Japan, Taiwan, Hong Kong, South Korea and Singapore. Instead, China has moved to center stage. Given the fact that China was barely touched upon in The Long Twentieth Century, Arrighi thus has to "fit" the Chinese ascent into his 
analysis of the development of the world-system. Furthermore, he has to demonstrate how this ascent has the potential to steer the very nature of the global economy away from capitalism, and toward a market society. These points were raised most poignantly by his long-time friend Andre Gunder Frank who believed that the resurgence of East Asia caught Arrighi in "an irresolvable contradiction":

First he claims capitalism began in the Italian cities and from there went through successive cycles of financial revolution [...]. At the same time and more so since, Giovanni has discovered China and its central place in world economic development although of course it had little or no part in the institutional development of capitalism based in Europe. The only resolution of Giovanni's knot, I argue, is to cut the Gordian knot of capitalism all together (Frank 2005:s.p.)

In Frank's view, Arrighi's original neglect to put China into the world-historical equation was a direct consequence of his Eurocentric understanding of historical capitalism. According to Frank, Arrighi and Wallerstein unwisely reduced capitalist history to the expansionist transformation of the Eurpean world-economy during the last five or seven centuries, whereas he wanted to stress the existence and relevance of a world system that centered on Asia long before the nineteenth century and might re-center on Asia in the near future (Frank 1998; Frank and Gills 1993). Wallerstein and Arrighi had serious problems with Frank's attempt to slay the Eurocentric demon and pull the rug out from under the feet of Western social theory (Wallerstein 1999, Arrighi $1999 \mathrm{~b}$ ). Arrighi criticized Frank for negating 'the undeniable specificity of the modern era, as defined by the extraordinary expansionary thrust of the Euro-centric system both absolutely and relative to the Sinocentric system" (Arrighi 1996:6). But this implies of course that Arrighi needs to contrast the differences between this "Euro-centric" capitalist system and the "Sinocentric" system, and deal with their presumed convergence at present.

\section{REVISITING THE LONG TWENTIETH CENTURY}

Arrighi attempts to solve Frank's "irresolvable contradiction" not by abandoning the theory of historical capitalism, but by elaborating the systemic cycles of accumulation perspective articulated in The Long Twentieth Century. On the one hand, Adam Smith puts stronger emphasis on the characterization of the emerging European world-economy after about 1300 as capitalist, in contrast to an East-Asian non-capitalist but market-based world-economy. On the other hand, the East-Asian world-economy is not considered to be subordinated to a globalizing, originally European, capitalist world-economy once the European gunpowder empires gradually unlocked China during the nineteenth century. On the contrary, the convergence of the European and EastAsian "paths of development", in Arrighi's view, creates the opportunity for an emerging noncapitalist, Sino-centered commonwealth of civilizations. We concur that the first supplement convincingly confirms the architecture of The Long Twentieth Century. The second revision however is much more problematic as Arrighi assumes but never accounts for the survival of a seeming Asian market-oriented legacy into a European, and later on North-American, politicalmilitary interaction network. 


\section{JOURNAL OF WORLD-SYSTEMS RESEARCH}

Let us start with the first supplement. The contrast between a European capitalist worldeconomy and an East-Asian market-based society immediately brings us back to Braudel's distinction between market competition and its capitalist antithesis. Arrighi paints the East-West regional contrast by recalling Adam Smith's distinction between a "natural" and an "unnatural," or retrograde, path of economic development. On the natural path, the greater part of capital is directed first to agriculture, next to manufactures, and last of all to foreign commerce. On the unnatural path, the vector of economic development is inverted, as foreign commerce demands finer manufactures that are fit for trade, while manufactures and foreign commerce together give birth to the principal improvements in agriculture. Smith believed the modern states of Europe walked down the unnatural path:

But though this natural order of things must have taken place in some degree in every such society, it has, in all the modern states of Europe, been, in many respects, entirely inverted. The foreign commerce of some of their cities has introduced all their finer manufactures, or such as were fit for distant sale; and manufactures and foreign commerce together have given birth to the principal improvements of agriculture. The manners and customs which the nature of their original government introduced, and which remained after that government was greatly altered, necessarily forced them into this unnatural and retrograde order (Smith 1991:340).

Arrighi agrees with Smith that Chinese economic development fits the natural path until the nineteenth century. Following the Opium Wars (1839-1860), China was opened up to foreign trade under European pressure. This meant that China was confronted with Smith's identified unnatural order of things. Ideal typical as these classifications are, and despite the fact that they make long-distance trade the mother of all inventions in Europe, Arrighi accepts the distinction. Although he admits that trade was important to both European and East-Asian states, he stresses that the economic and political weight of long-distance trade relative to short-distance trade was far greater in the European than in the East Asian system (Arrighi 2007a:319). He recalls how this long-distance, East-West trade was vital to the fortunes of Venice, instigated the "discovery" of America, and created unseen opportunities for the Dutch and British merchants and chartered companies. In contrast, the Ming dynasty (1368-1644) instigated a policy that privileged the domestic market over foreign trade, a policy that was relaxed now and then, but resumed with the consolidation of Qing rule in 1644. In short, the East Asian system was not directed towards geographical expansion but towards state- and national economy-making. The most frequent acts of war were aimed at safeguarding China's northern border, not at the extension of this border. In sharp contrast to the extraversion and expansionist tendencies of the modern European States, the East-Asian State components did not build overseas empires in competition with one another or engaged in an armament race in any way comparable to the European states (Arrighi 2007a:313$316)^{4}$

\footnotetext{
${ }^{4}$ In contrast to Wallerstein, the differences between the East Asian and European system are not painted in terms of a European inter-state system versus a East-Asian world-empire, in which China would act as the imperial centre and concentrates political, economic and cultural power (see Wallerstein 1974:63). As Arrighi points out, Great Britain fulfilled a similar role in the European system during the nineteenth
} 
Arrighi does not deny the presence of profit-seeking agencies in China. However, in line with Braudel (1984), Bin Wong (1997) and Pomeranz (2000), Arrighi postulates that these capitalists were never able to promote their search for the accumulation of capital as the cornerstone of national economic development, which was instead aimed at feeding and protecting the empire. This East Asian path blocked the synergy between militarism, capitalism, industrialization and territorial expansion which characterized European development. This path also made East Asia and China no match for the European states when they forced the opening of China in the south, where the equivalent of a Chinese wall was missing.

This juxtaposition between a European and East-Asian world-economy not only confirms the narrative of The Long Twentieth Century on the creation of a European capitalist world-economy, it also allows Arrighi to reconsider the interaction between the two systems. Whereas the longstanding trade between Eastern and Western Eurasia influenced Frank to postulate the existence of a 5000 year old world system, Arrighi reconstructs two different worldeconomies that rested upon different institutional settings through which this trade took place. East-West trade fitted the capitalist rationale that buttressed the European world-economy, but remained of minor importance to the political economy that ruled the East-Asian inter-state system. This is why long-distance trade may have brought the most advanced capitalism to the shores of the Far East, but never encompassed Eastern society to the extent it did on the Far West of the Eurasian landmass (Braudel 1982:124). What Frank presents as an irresolvable contradiction between China's central place in global economic development and Arrighi's model of the institutional development of capitalism based in Europe, is solved by reaffirming the different political economy structure in Europe and East-Asia. Profit-seeking stimulated European agencies to step outside of the European world-economy but when they did they penetrated another world-economy, they did not act within one Eurasian world system. The difference on this point between Frank and Arrighi is quite clear (Denmark 2009:236).

\section{Beyond the Great Divergence}

Up to this point, Arrighi faced few problems in comparing the East Asian trajectory with the European one. The real challenge, as expected, starts once China and East Asia are "subordinated to Western commands", to quote one of the few passages in The Long Twentieth Century on China (Arrighi 1994:48). If China in particular, and East Asia in general, walked down a radically different developmental path than Europe, what happens when these paths converge? Does the market logic of the East dissolve within a capitalist world-economy that has become "all powerful and truly global" (Arrighi 1994:11)? In our view, Arrighi has altered this proposition in different ways and on different occasions since The Long Twentieth Century. In 1996 he replies to Gunder Frank that "capitalism as a mode of rule and accumulation did become dominant, first in Europe and then globally." But he adds that capitalism "never completely lost its interstitial character, which is as evident in today's emerging center of world capitalism (East Asia) as in its original sixteenth-century center (Western Europe)" (Arrighi 1996: 27-28). The key word here is the rather confusing "interstitial character" of capitalism. What Arrighi refers to is the fact that

century. And although this brought about Europe's remarkable Hundred Years Peace (1815-1914), the interstate competition was continued at the outer rims of the by then globalizing European system, as European states scrambled for Africa and knocked down the walls of Imperial China. 


\section{JOURNAL OF WORLD-SYSTEMS RESEARCH}

capitalism as a rule of accumulation in Europe predates the rise of the modern states and is thus perfectly able to survive in many different political economic configurations, such as city-states, quasi-empires, and business diasporas. The question then is of course how a shift of the economic center to the East would entail "the end of capitalism as we knew it", given the fact that capitalism always had an "interstitial character" and as mode of rule and accumulation has become dominant?

Three years later, in Chaos and Governance in the Modern World-System, Arrighi, Ahmad and Shih (1999:248-49) underscore the "formal dissolution" of the China-centered worldsystem under European expansion. But they add that despite the formal dissolution of the structures and norms of the East Asian system, these structures nevertheless persisted, and "continued to shape and influence interstate relations within East Asia". Despite the incorporation of East Asia into the global circuits of power, Arrighi and Silver maintain that Western intrusion destabilized and transformed a China-centered world system, "but never managed to destroy and create it in the Western image":

All the region's most important nations that were formally incorporated in the expanded Westphalia system - from Japan, Korea, and China, to Vietnam, Laos, Kampuchea, and Thailand - had all been nations long before the European arrival. What's more, they had all been nations linked to one another, directly or through the Chinese center, by diplomatic and trade relations and held together by a shared understanding of the principles, norms, and rules that regulated their mutual interactions as a world among other worlds (Arrighi and Silver 1999:287).

Chaos and Governance never makes clear what East Asia's shared principles, norms, and rules exactly are, nor how they survived a century of "destabilization". Instead, Arrighi and Silver conclude with the vague proposition that "the leading states of the West are prisoners of the developmental paths that have made their fortunes, both political and economic" and that "East Asia must open up a new path of development for [itself] and the world that departs radically from the one that is now at a dead end." (Arrighi and Silver 1999:288-289) Adam Smith rephrases the same propositions in a more sophisticated manner, making use of Adam Smith's proposition on the natural and unnatural paths of development. Whereas Chaos and Governance posited that the subordinate incorporation of the China-centered world-system did not destroy the pre-existing Sino-centric system of international relations, Adam Smith additionally argues that this survival of the Sino-centric system "contributed to the ongoing transformation of the incorporating Western system itself" (Arrighi 2007a:313). In conclusion, it is clear that Arrighi considerably modified the original idea of China's "subordination to the Western commands" that was presented in The Long Twentieth Century. Instead he has come to favor "hybridization" between the two distinct paths of developments, one capitalist and one not. And within this hybrid construct he stresses the resilience of the market-logic that prevailed in China in particular (despite the active distortion of market forces up until 1979 and the active promotion of profit-seeking after 1979). 


\section{THE FUTURE OF THE WORLD ECONOMY}

The analytical reconstruction of The Long Twentieth Century is motivated by Arrighi's present political concerns. Especially the resilience of the market-logic, still prevailing in East Asia despite a century of convergence with the "unnatural" capitalist path, serves as a crucial precondition for Arrighi's hope for a future market-based commonwealth that is no longer dominated by the endless accumulation of capital. The future will of course show whether Arrighi's utopistics holds any validity or if, East Asia's economic growth (when, or if, continued) will bring little systemic change about. ${ }^{5}$ But already within the analytical architecture of $\mathrm{Adam}$ Smith, the connection between its historical narrative and contemporary examination is, to use the expression by Abu-Lughod, "provocative but filled with hypothetical conjectures and unproven reasoning" (Abu-Lughod 2009). Even if one agrees that a shift in the epicentre of the global political economy is taking place from North America to East Asia, few people interpret this shift as the end of capitalism as we know it, despite the different economic trajectory the region might have walked down in the past (for a discussion see Abbeloos 2008; Clark 2008; Coyne 2009; Dyer 2007; Gulick 2009; Trichur and Sherman 2009; Walden 2007). There are few signs that China's recent economic development challenges a capitalist logic of power and accumulation. Joel Andreas agrees that the economy was indeed non-capitalist in the distant and recent past, both in the Marxist sense as a mode of production and in the Braudelian sense as a mode of rule and accumulation, but argues that because of "the radical reforms carried out in recent years, the non-capitalist market economy that existed in the 1980s has been transformed into a capitalist economy:

There is no longer a socialist sector and virtually all enterprises that employ more than a handful of people, whether they are publicly or privately owned, now operate according to capitalist principles. [...] a distinctive characteristic of the present-day Chinese system is the extent to which capital is organized around the state apparatus, an intricate web in which influence runs in both directions. [...] as things stand, this development would refashion rather than transcend the existing capitalist order (Andreas 2008:133,139,141).

A new type of "political exchange" within China between governmental and business agencies does not seem to be one in which the former can still keep the latter in check. Or put in a more Marxist fashion, Arrighi admits that it is difficult to assess "whether the Chinese government is in the process of becoming a committee for managing the common affairs of its national bourgeoisie." (Arrighi 2007a:359) Concerning its role in world politics, China seems to look beyond its borders for much the same reasons rising powers have done so in the past. China is hungry for Latin American, and especially African, natural resources (such as copper) to fuel its rapidly growing economy. It is true that African political leaders themselves do not always look at China as the new imperial power on the block, but sometimes welcome its investments as a

\footnotetext{
${ }^{5}$ As is clear from Adam Smith, Arrighi never seriously considers the possibility that an Eastern shift in the epicentre of the global political economy might simply ignite another cycle of accumulation. When David Harvey in an interview confronted Arrighi with this possibility, his answer is, as Bair noted, "somewhat elusive". (Bair 2009:225; for the interview see Arrighi 2009).
} 
wave of South-South cooperation that is not subject to the same conditional ties which characterize Western investments (Sautman and Hairong 2007). On the other hand, this suggested Beijing consensus and its emphasis on national sovereignty and multilateralism may be little more than a pretext to do business with both democratic and authoritarian regimes, serving as a legitimization of the type of hands off policy China has applied to the human rights crisis in Sudan. Looking back half a century, this Beijing consensus and its positive acceptance in peripheral countries seems to resemble both the message and acceptance of the United States' "right to self-determination" after the Second World War:

The United States was thus able to pose during the Second World War as the natural ally of the emergent nationalism in the colonial empires, and as the guarantor of the promises of self-determination and national independence [...], the model of the 'Revolution of 1776' was not merely an American propaganda weapon for use in the colonial world, but also a spontaneous source of inspiration for the colonial peoples themselves. [...] Towards the end of the 1940's, however, the nationalist tendencies of the colonial world began to diverge from the expansionist tendencies of the United States (Arrighi 1978:93-94).

Analogous to the American example of the mid-twentieth century, a Chinese hands off policy is easy to uphold as long as the African countries are in no position to push for a number of developmental obligations that conflict with the expansionist tendencies of the Chinese economy. It remains to be seen what Beijing will do once African states will seek to drive up the bargain in meeting the Chinese demand for resources (for an in depth discussion see Alden 2007).

To conclude, Arrighi knows he is making uncertain projections into an uncertain future. Adam Smith for example ends with the warning that, "by relying too heavily on the energyconsuming Western path, China's rapid economic growth has not yet opened up for itself and the world an ecologically sustainable developmental path" (Arrighi 2007a:398). The political message of Adam Smith in Beijing holds that the future of the world will not be determined by the Euro-American powers, and that this future might be bright if China and other Southern states reorient their policies towards a path of balanced development, socially and ecologically. Straightforward as it may be, it feels a bit uncomfortable to see an ambitious book that practically suffers from too much sophisticated theoretical reflections end in such a circumspect conclusion. Or put in another way, if Arrighi's model of The Great Divergence and Convergence proves to be a hard template to understand the place of China within an integrating global economy, the model gives even less guidance to understand the prospects of this global economy.

\section{CONCLUSION: WHAT REMAINS OF THE CAPITALIST WORLD-SYSTEM?}

Adam Smith in Beijing is an attempt to answer the question that Arrighi left hanging at the end of The Long Twentieth Century: "Can capitalism survive success?" We may now rephrase the question: "What remains of the capitalist world-system?" The question runs in two directions, past and present. First, Arrighi hopes that at present, the capitalist world-system might give way to Adam Smith's commonwealth of civilizations (Arrighi 2007a:10). Regarding these utopistics, we emphasize that Arrighi knows he makes uncertain projections into an uncertain future. 
Second, and more fundamental to world-systems analysis, these projections are based on, or rather motivate, a model of the Great Divergence and Convergence that aims to supplement The Long Twentieth Century but creates new ambiguities in doing so. Given that the aim of worldsystems analysis, in the words of Wallerstein, is about offering "more plausible explanations of historical reality" (2007:19), Arrighi's conceptual struggles with capitalism and the worldeconomic unit do not seem to lead to a better understanding of the Gordian knot of World History. We agree with Christopher Chase-Dunn that Arrighi "does far better than Frank" in seeing that until deep in the nineteenth century East Asia and Europe threaded down different developmental paths, and that there was a substantially independent East Asian international system prior to the nineteenth century (Chase-Dunn 2009). However, the real problem is Arrighi's assumption that Asia's market-oriented legacy survived within a European, and later, a North American, political-military interaction network. Characterized as a process of subordination, formal dissolution or hybridization, it is difficult to understand the place of China and East Asia within the world during the long $20^{\text {th }}$ century. Adam Smith presents an impressive historical analysis to remind us that world history is not a teleological march towards Fukuyama's End of History (1993), but this does not automatically render Arrighi's speculations on the "End of Capitalism" more credible. East Asia may not have had an inherent tendency to generate the capital- and energy-intensive developmental path opened up by Britain, but one could argue that it is emulating this path today to the full extent.

In sum, what stimulated much of Arrighi's research but finally turned against him is his "presentist" approach to historical sociology (Moore 1997:105). Ever since The Geometry of Imperialism (1978), Arrighi's main concern lay with the future directions of the world economy and how to understand the economic downturn of/since the seventies. Moore stresses that this attitude allowed Arrighi to discern long-run cycles with tremendous clarity but made him vulnerable to the very problem World-Systems Analysis aims to remedy: an ahistorical analysis of the evolution of capitalism. The problem with Adam Smith is not so much that the analysis once more risks to ahistorical argument, but that this time around, the analysis has lost some of its tremendous clarity. Instead of fine tuning the rigorous model Arrighi presented in The Long Twentieth Century, we are offered a supplement that does fairly little to cut The Gordian knot of the Great Divergence and Convergence. Nor does Adam Smith address other problems with The Long Twentieth Century such as its underestimation of technological factors in the study of the global economy (Elvin 2008:92-93). Despite these problems, The Long Twentieth Century's analysis of "long centuries" of converging and diverging relationships between the production of wealth, power and space in the history of capitalism stands as one of the most stimulating in the historical sociological literature. It deserves to be criticized, updated and tested, but "unthinking" it in the light of an East Asian development with an unclear outcome seems a big risk to take and it might not be the most promising option to understand much of this development itself.

\section{ACKNOWLEDGEMENTS}

An earlier version of this text was used for a roundtable discussion of Adam Smith in Beijing and Arrighi's intellectual legacy, organized by Eric Vanhaute during the 2009 World Economic History Conference in Utrecht. We thank the participants to this discussion, Peer Vries, Kenneth 
Pomeranz, Patrick O'Brien and Kaoru Sugihara, for their reflections. The writing of this article also benefited from the suggestions made by the reviewers.

REFERENCES

Abbeloos, Jan-Frederik. 2008. "La Chine, dernière chance du capitalism?" La Revue Internationale des Livres et des Idées 8:28-31.

Abu-Lughod, Janet. 2008. "Review of Adam Smith in Beijing." Trajectories, Newsletter of the Comparative and Historical Sociology Section of the ASA 20(1):15-18.

Alden, Chris. 2007. China in Africa. London: Zed Books.

Allen, Robert C. 2009. The British Industrial Revolution in Global Perspective. New York: Cambridge University Press.

Andreas, Joel. 2008. "Changing Colours in China." New Left Review 54:123-142.

Arrighi, Giovanni. 1978. Geometry of Imperialism. The Limits of Hobson's Paradigm. London: Verso.

. 1994. The Long Twentieth Century. Money, Power and the Origins of Our Times. London: Verso. . 1996. "The Rise of East Asia and the Withering Away of the Interstate System." Journal of World-Systems Research 15(2):1-28.

. 1999a. "Globalization, State Sovereignty, and the 'Endless' Accumulation of Capital." Pp. 53-73 in State and Sovereignty in the World Economy, edited by David Alden Smith, Dorothy J. Solinger and Steven Topik. London: Routledge.

. 1999b. "The World According to Andre Gunder Frank." Review: A Journal of the Fernand Braudel Center 22(3):327-354.

. 2000. "Globalization and Historical Macrosociology." Pp. 117-133 in Sociology for the Twenty-First Century. Continuities and Cutting Edges, edited by Janet Abu-Lughod. Chicago: Chicago University Press. . 2007a. Adam Smith in Beijing. Lineages of the Twenty-First Century. London: Verso. . 2007b. "States, Markets, and Capitalism, East and West." Positions 15(2):251-284. . 2009. "The Winding Paths of Capital. Interview by David Harvey." New Left Review 56:61-94.

Arrighi, Giovanni and Beverly J. Silver. 1999. "Conclusion." Pp. 271-289 in Chaos and Governance in the Modern World System, edited by Giovanni Arrighi and Beverly J. Silver. Minneapolis: University of Minnesota Press.

Arrighi, Giovanni, Iftikhar Ahmad and Miin-wen Shih. 1999. "Western Hegemonies in WorldHistorical Perspective." Pp. 217-270 in Chaos and Governance in the Modern World System, edited by Giovanni Arrighi and Beverly J. Silver. Minneapolis: University of Minnesota Press.

Bair, Jennifer. 2009. "The New Hegemon? Contingency and Agency in the Asian Age." Journal of World-Systems Research 15(2):220-227.

Bin Wong, Roy. 1997. China Transformed: Historical Change and the Limits of European Experience. New York: Cornell University.

Braudel, Fernand. 1958. "Histoire et sciences sociales: La longue durée." Annales. Histoire, Sciences Sociales 13(4):725-753 
1981, 1982, 1984. Civilization and Capitalism 15th-18th Century Volume I: The Structures of Everyday Life, the Limits of the Possible. Volume II: The Wheels of Commerce. Volume III: The Perspective of the World. London: Collins.

Brenner, Robert. 1977. "The Origins of Capitalist Development: a Critique of Neo-Smithian Marxism." New Left Review 104:25-92.

Chase-Dunn, Christopher. Forthcoming. "Adam Smith in Beijing: A World-Systems Perspective." Historical Materialism.

Clark, Gregory. 2008. "China as the Antidote to Oppression and Exploitation?" The Chronicle Review 54(27):B16.

Coyne, Gary. 2009. "Natural and Unnatural Paths." Journal of World-Systems Research $15(2): 228-232$.

Denmark, Robert. 2009. World System History: Arrighi, Frank, and the Way Forward." Journal of World-Systems Research 15(2):233-242.

Dyer, Geoff. 2007. "Enter the Dragon." Financial Times, November 2.

Elvin, Mark. 2008. "The Historian as Haruspex." New Left Review 52:83-109.

Ferguson, Niall. 2006. The War of the World. Twentieth-Century Conflict and the Descent of the West. New York: The Penguin Press.

Flynn, Dennis O. and Arturo Giráldez. 2004. "Path Dependence, Time Lags, and the Birth of Globalisation: A Critique of O'Rourke and Williamson." European Review of Economic History 8(1):81-108.

. 2008. 'Born Again: Globalization's Sixteenth Century Origins (Asian/Global Versus European Dynamics)." Pacific Economic Review 13(3):359-87.

Frank, Andre Gunder and Barry K. Gills. 1993. "The 5000-year World System: An Interdisciplinary Introduction." Pp. 3-55 in The World System. Five Hundred Years or Five Thousand?, edited by Andre Gunder Frank and Barry K. Gills. London: Routledge.

Frank, Andre Gunder. 1998. ReOrient. Global Economy in the Asian Age. Berkeley: University of California Press.

. 2000. "Immanuel and Me With-Out Hyphen." Journal of World-Systems Research 6:216231.

. 2005. Changes in My View about Dependence and Capitalism [http://www.rrojasdatabank.org/agfrank].

Fukuyama, Francis. 1993. The End of History and the Last Man. New York: Avon Books.

Ganesh, Trichur and Steven Sherman. 2009. "Giovanni Arrighi in Beijing." Journal of WorldSystems Research 15(2): 256-263.

Glyn, Andrew. 2005. "Imbalances of the Global Economy." New Left Review 34:5-37.

Goldstone, Jack A. (2009). "From Sociology and Economics to World History." Österreichische Zeitschrift für Geschichtswissenschaften 20(2):75-90.

Gulick, John. 2009. "Giovanni Arrighi's Tapestry of East \& West." Journal of World-Systems Research 15(2):243-248.

Jones, Eric L. 1981. The European Miracle: Environments, Economies, and Geopolitics in the History of Europe and Asia. Cambridge: Cambridge University Press.

Laclau, Ernesto. 1971. "Feudalism and Capitalism in Latin America." New Left Review 67:19-38.

Landes, David S. 1969. The Unbound Prometheus: Technological Change and Industrial Development in Western Europe from 1750 to the Present. Cambridge: Cambridge University Press. 
Little, Daniel. 2008. "Eurasian Historical Comparisons. Conceptual Issues in Comparative Historical Inquiry." Social Science History 2:235-261.

MeNeill, William H. 1992. The Rise of the West: A History of the Human Community. Chicago: University Of Chicago Press.

Moore, Jason W. 1997. "Capitalism over the Longue Duree: A Review Essay." Critical Sociology 23(3): 103-116.

Nef, John U. 1934. "The Progress of Technology and the Growth of Large-Scale Industry in Great Britain, 1540-1640." The Economic History Review 5(1):3-24.

Pomeranz, Kenneth. 2000. The Great Divergence. Europe, China, and the Making of the Modern World Economy. New York: Princeton University Press.

Pritchett, Lant. 1997. 'Divergence, Big Time." The Journal of Economic Perspectives 11(3):3-17.

Reifer, Thomas. 2009. "Histories of the Present: Giovanni Arrighi \& The Long Duree of Geohistorical Capitalism." Journal of World-Systems Analysis 15(2):249-256.

Sachs, Jeffrey D. 2008. Common Wealth. Economics For a Crowded Planet. New York: The Penguin Press.

Sautman, Barry and Yan Hairong. 2007. 'Friends and Interests: China's Distinctive Links with Africa." African Studies Review 50(3):75-114.

Schumpeter, Joseph. 1976. Capitalism, Socialism, and Democracy. New York: Allen \& Unwin.

Smith, Adam. 1991. An Inquiry into the Nature and Causes of the Wealth of Nations. London: Everyman's Library.

Sugihara, Kaoru. 2003. "The East Asian Path of Economic Development: A Long-term Perspective." Pp. 78-123 in The Resurgence of East Asia. 500, 150 and 50 Year Perspectives, edited by Giovanni Arrighi, Takeshi Hamashita and Mark Selden. London and New York: Routledge.

Van Zanden, Jan Luiten. 2008. "The Road to the Industrial Revolution: Hypotheses and Conjectures about the Medieval Origins of the "European Miracle'." Journal of Global History 3:337-359.

Vries, Peer. 2005. "Is California the Measure of All Things Global? A Rejoinder to Ricardo Duchesne." World History Connected 2(2):s.p.

. 2008. "The California School and Beyond: How to Study the Great Divergence?" Journal für Entwicklungspolitik/Austrian Journal of Development Studies 24(4):6-49.

. 2009. "Global Economic History: A Survey." Österreichische Zeitschrift für Geschichtswissenschaften 20(2): 133-169.

Walden, George. 2007. "Adam Smith Goes to China, Marxists Cheer in Dodgy New Orthodoxy." Bloomberg News, November 18.

Wallerstein, Immanuel. 1974, 1980, 1989. The Modern World-System. Volume I: Capitalist Agriculture and the Origins of the European World-Economy in the Sixteenth Century. Volume II: Mercantilism and the Consolidation of the European World-Economy, 16001750. Volume III: The Second Ear of the Great Expansion of the Capitalist WorldEconomy, 1730-1840s. New York: Academic Press. 1989. Historical Capitalism. London: Verso.

. 1991. "Braudel on Capitalism, or Everything Upside Down." Journal of Modern History 63:354-61. 
. 1993. "World System versus World-Systems." Pp. 292-296 in The World System. Five Hundred Years or Five Thousand?, edited by Andre Gunder Frank and Barry K. Gils. London: Routledge,.

. 1999. "Frank Proves the European Miracle." Review: A Journal of the Fernand Braudel Center 22(3):355-371.

. 2004. Introduction to World-Systems Analysis. Durham: Duke University Press.

. 2005. "After Developmentalism and Globalization, What?" Social Forces 83(3):12631278.

Weber, Max. 2003. Protestant Ethic and the Spirit of Capitalism. New York: Dover Publications. Williams, Eric. 1994. Capitalism and Slavery. New York: The University of North Carolina Press.

Wrigley, E.A. 1988. Continuity, Chance and Change: The Character of the Industrial Revolution in England. New York: Cambridge University Press. 